American Journal of Pharmaceutical Education 2017; 81 (7) Article 6265.

\title{
EDUCATION BRIEF
}

\section{Educational Gaming for Pharmacy Students - Design and Evaluation of a Diabetes-themed Escape Room}

\author{
Heidi N. Eukel, PharmD, Jeanne E. Frenzel, PharmD, Dan Cernusca, PhD \\ North Dakota State University, Fargo, North Dakota \\ Submitted January 9, 2017; accepted April 12, 2017; published September 2017.
}

Objective. To design an educational game that will increase third-year professional pharmacy students' knowledge of diabetes mellitus disease management and to evaluate their perceived value of the game.

Methods. Faculty members created an innovative educational game, the diabetes escape room. An authentic escape room gaming environment was established through the use of a locked room, an escape time limit, and game rules within which student teams completed complex puzzles focused on diabetes disease management. To evaluate the impact, students completed a pre-test and post-test to measure the knowledge they've gained and a perception survey to identify moderating factors that could help instructors improve the game's effectiveness and utility.

Results. Students showed statistically significant increases in knowledge after completion of the game. A one-sample $t$-test indicated that students' mean perception was statistically significantly higher than the mean value of the evaluation scale. This statically significant result proved that this gaming act offers a potential instructional benefit beyond its novelty.

Conclusion. The diabetes escape room proved to be a valuable educational game that increased students' knowledge of diabetes mellitus disease management and showed a positive perceived overall value by student participants.

Keywords: pharmaceutical care laboratory, diabetes mellitus, gaming, educational game, serious gaming

\section{INTRODUCTION}

Pharmacists provide valuable diabetes disease management to patients to improve health outcomes and decrease health care-associated costs. ${ }^{1,2}$ Hands-on diabetes training programs can increase student competence and self-confidence to provide diabetes care. ${ }^{3}$ Numerous colleges and schools of pharmacy have developed instructional methods and simulations to enhance student learning of diabetes management topics. ${ }^{3}$ The 2013-2014 American Association of Colleges of Pharmacy (AACP) Academic Affairs Committee report encouraged the development of serious games in pharmacy education to prepare future pharmacists for practice. The policy report states "AACP supports the use and development of serious games to enhance pharmacy and interprofessional education."4

This educational brief will focus on the design and assessment of an innovative educational game, the diabetes escape room, used to increase student knowledge of diabetes disease management in a skills laboratory course and evaluate their perceived value of the game. The goal

Corresponding Author: Heidi Eukel, North Dakota State University, 1340 Administration Ave., Fargo, ND. Tel: 701231-7602. E-mail: Heidi.Eukel@ndsu.edu of the teaching innovation was to fully engage learners in learning by doing. 5,6

\section{METHODS}

To complement and reinforce nine hours of prior didactic instruction in diabetes mellitus, an innovative educational game, the diabetes escape room, was designed, implemented, and assessed. Escape rooms are "live-action team-based games where players discover clues, and solve puzzles [...] in order to accomplish a specific goal, usually escaping from the room, in a limited amount of time." ${ }^{77}$ Six two-hour skills laboratory sections taught by two pharmacist faculty included up to 15 third-year professional pharmacy students (P3) divided into three teams of five. Eighty-three P3 students completed the activity over the course of four days. The goal for each team was to gain access to a glucagon placebo injection for a pediatric patient with type I diabetes who was experiencing life-threatening hypoglycemia. Obtaining and demonstration administration of the glucagon placebo injection allowed teams to escape the room. Faculty developed four complex puzzles focused on diabetes treatment topics that emphasized hands-on exploration of medications and diabetes-related products. A variety of puzzle 


\section{American Journal of Pharmaceutical Education 2017; 81 (7) Article 6265.}

types were used to elicit student engagement in the activity (Table 1). Students had 75 minutes to gather clues from the four puzzles and escape the room.

The gaming environment was a simulated child's bedroom that contained clues on how to escape from the room. The patient's life-saving medication was in a locked cabinet in the bedroom. Teams received a survival kit including four hint cards and three iPad passes. At their discretion, teams could request hints from faculty or the use of an iPad to access treatment guidelines or drug information resources. Each room had a live video stream allowing faculty to observe group interactions. The live

Table 1. Diabetes Escape Room Puzzles

\begin{tabular}{|c|c|c|c|}
\hline & Educational Topics & Skill Demonstration & Gaming Tasks \\
\hline$\overline{\text { Puzzle } 1}$ & $\begin{array}{l}\text { Mechanism of action of } \\
\text { oral antidiabetic } \\
\text { medications }\end{array}$ & $\begin{array}{l}\text { Demonstrate oral antidiabetic therapy } \\
\text { recommendation; } \\
\text { Demonstrate ability to match mechanism of } \\
\text { action of oral antidiabetic medications; } \\
\text { Demonstrate ability to match medication } \\
\text { classification of oral antidiabetic } \\
\text { medications; } \\
\text { Demonstrate consultation }{ }^{\text {a }} \text { of oral antidiabetic } \\
\text { medication. }\end{array}$ & $\begin{array}{l}\text { Mason cipher } \\
\text { Word jumble } \\
\text { Coded message }\end{array}$ \\
\hline Puzzle 2 & $\begin{array}{l}\text { Carbohydrate counting } \\
\text { Sliding scale insulin dosing } \\
\text { Insulin pen consultation } \\
\text { Use of insulin syringe }\end{array}$ & $\begin{array}{l}\text { Demonstrate ability to investigate a patient's } \\
\text { personal blood glucose log; } \\
\text { Accurately perform carbohydrate counting; } \\
\text { Demonstrate live consultation }{ }^{\text {a }} \text { of insulin pen; } \\
\text { Demonstrate ability to accurately measure } \\
\text { medication using an insulin syringe. }\end{array}$ & $\begin{array}{l}\text { Sudoku } \\
\text { Combination lock decoding } \\
\text { Math riddle } \\
\text { Data hunt }\end{array}$ \\
\hline Puzzle 3 & $\begin{array}{l}\text { Injectable antidiabetic agents } \\
\text { mechanism of action } \\
\text { Patient education and } \\
\text { administration } \\
\text { demonstration } \\
\text { Micro- and macrovascular } \\
\text { complications } \\
\text { Hyper- and hypoglycemia: } \\
\text { signs, symptoms, treatments } \\
\text { Mixing insulin }\end{array}$ & $\begin{array}{l}\text { Utilize a paper-based medical chart to answer } \\
\text { a provider request; } \\
\text { Calculate dose for glucose tabs based on } \\
\text { hypoglycemia symptoms; } \\
\text { Demonstrate consultation }{ }^{\text {a }} \text { of injectable } \\
\text { antidiabetic medications (non-insulin); } \\
\text { Identify accurate procedure for mixing insulins; } \\
\text { Identify signs and symptoms of hyperglycemia } \\
\text { and appropriate treatment; } \\
\text { Identify signs and symptoms of hypoglycemia } \\
\text { and appropriate treatment. }\end{array}$ & $\begin{array}{l}\text { Jeopardy } \\
\text { Data hunt } \\
\text { Dose calculations }\end{array}$ \\
\hline Puzzle 4 & $\begin{array}{l}\text { Treatment guidelines } \\
\text { Preventive care } \\
\text { Goals of therapy } \\
\text { Immunization recommendations } \\
\text { Monofilament exam } \\
\text { Laboratory monitoring }\end{array}$ & $\begin{array}{l}\text { Demonstrate ability to navigate an electronic } \\
\text { medical record; } \\
\text { Evaluate a patient's electronic medical record to } \\
\text { provide recommendations for preventive } \\
\text { care, goals of therapy, and immunization } \\
\text { recommendations; } \\
\text { Identify appropriate laboratory monitoring } \\
\text { based on patient's medication profile in } \\
\text { electronic medical record; } \\
\text { Demonstrate a diabetic foot exam on a peer } \\
\text { using monofilament. }\end{array}$ & $\begin{array}{l}\text { Data hunt } \\
\text { Rebus puzzle }\end{array}$ \\
\hline Final Puzzle & $\begin{array}{l}\text { Severe hypoglycemia } \\
\text { management }\end{array}$ & $\begin{array}{l}\text { Demonstrate consultation }{ }^{\mathrm{a}} \text { of glucagon; } \\
\text { Demonstrate ability to administer glucagon } \\
\text { using a glucagon placebo training kit. }\end{array}$ & Interpretive puzzle \\
\hline
\end{tabular}

${ }^{\mathrm{a}}$ Consultation: live demonstration to a peer using placebo product; OBRA '90 requirements; open-ended questions; faculty observation with formative feedback

${ }^{\mathrm{b}}$ American Diabetes Association 


\section{American Journal of Pharmaceutical Education 2017; 81 (7) Article 6265.}

video stream was established at no cost through Google Hangout connections between iPads and computer. Faculty observed student demonstration of a monofilament foot exam, explanations of medication administration devices, and patient consultation skills via the live feed.

All teams began simultaneously with puzzle 1 . Teams had to solve puzzle 1 and demonstrate a comprehensive consultation for them to advance to puzzle 2 and earn a token toward the final puzzle. To proceed to the next round, teams had to solve puzzle 2 and demonstrate appropriate administration technique and comprehensive consultation. At the completion of both items, teams received a second token and puzzle 3 . They then had to solve puzzle 3 in order to navigate a medical chart to respond to a provider information request. At the completion of both items, teams received a third token and puzzle 4. In this round, teams had to use an electronic health record and demonstrate a diabetic foot exam to solve puzzle 4 and to receive the fourth and final token. The teams then use all four tokens to decipher the diabetesthemed pictograph to find the key that will unlock the patient's medication box that contained the glucagon placebo injection. To successfully escape the room, students demonstrated the administration of glucagon.

In one of the puzzles, teams were given a locked lunchbox. Teams had to solve a Sudoku puzzle to unlock the lunchbox. The lunchbox contained a child's lunch, blood glucose log book, an insulin syringe, a carbohydrate counting guide, pen needles, recipe clippings from a magazine, and a Novolog pen placebo. Teams gathered clues from the blood glucose log book, insulin syringe, and the carbohydrate counting guide to calculate the total number of Novolog insulin units required for the meal in the lunchbox. An assigned student then demonstrated to faculty through the live video feed how to administer a Novo$\log$ pen and a complete consultation, in accordance with the Omnibus Budget Reconciliation Act of 1990 (OBRA '90), prior to receiving the next puzzle.

The research team used a cross-sectional pre- and post-test research design to assess students' changes in performance. Students had prior knowledge in diabetes mellitus from a previous and independent didactic course. Therefore, the diabetes escape room acted as a standalone valid instructional treatment for the proposed research design. All 83 P3 students were required to participate in the game and success in the game did not affect their performance in the course. For statistical analysis, the research team used SPSS, v23 (SPSS Inc., Chicago, IL).

Students participated in a 23-question multiple choice, true or false, and fill-in-the-blank knowledge assessment one week prior to and immediately after the game. The assessments were administered in Blackboard (Washington, DC), the learning management system used for the course. Questions assessed baseline knowledge of diabetes management and focused on injectable and oral antidiabetic medication, treatment guidelines, goals of therapy, and preventive screenings. The performance data related to the pre- and post-knowledge assessment were analyzed for outliers and normality. Two outliers identified in this dataset were removed. Both the analysis of kurtosis and skewness as well as the quantile-quantile (QQ) plots indicated an acceptable level of normality for the performance dataset.

Students were invited to complete a set of 12 questions developed by faculty to measure overall perceptions of the gaming activity including support for their own learning, nature of learning activity and team learning. The perception scale was a five-point Likert scale ranging from " $1=$ strongly disagree" to "5 = strongly agree." The dataset for the perception survey had no outliers and showed an acceptable level of normality.

The North Dakota State University Institutional Review Board approved the informed consent document and instruments used in this study.

\section{RESULTS}

Of the 83 students enrolled in the course, 74 (89\%) completed both the pre- and post-knowledge assessment. Students' mean score for the pre-knowledge assessment significantly predicted students' mean score for the postknowledge assessment, $\mathrm{F}(1,71)=18.8, p<.01$, and also explained a significant proportion of variance in postknowledge assessment score, $\mathrm{r}^{2}=.21$. Students' mean score for the post-knowledge assessment, $81 \%$, was statistically significantly higher than students' mean score for the pre-knowledge assessment, $56 \%, \mathrm{t}(72)=-18.1$, $p<.01$.

Seventy-nine students $(95 \%)$ completed the perception exit survey (Table 2). A one-sample $t$-test indicated that students' mean (SD) perception 4.1 (.50) was statistically significantly higher than the mean value of the evaluation scale, " $3=$ not agree nor disagree," $\mathrm{t}(78)=$ $19.6, p<.01$. This statically significant result suggests a strong impact of this game on students' perceptions suggesting a potential instructional benefit of this activity beyond the mere novelty factor.

\section{DISCUSSION}

Pharmacists play a vital role in the provision of diabetes disease management education to patients. To master this topic, students need opportunities to review and integrate course-based knowledge through hands-on 


\section{American Journal of Pharmaceutical Education 2017; 81 (7) Article 6265.}

Table 2. Diabetes Escape Room Perception Scale (N=79)

\begin{tabular}{|c|c|c|c|c|c|c|}
\hline Item & $\begin{array}{c}\text { Mean } \\
\text { (SD) }\end{array}$ & $\begin{array}{c}\text { Strongly } \\
\text { Disagree (\%) }\end{array}$ & $\begin{array}{c}\text { Disagree } \\
(\%)\end{array}$ & $\begin{array}{c}\text { Neutral } \\
(\%)\end{array}$ & $\begin{array}{c}\text { Agree } \\
(\%)\end{array}$ & $\begin{array}{c}\text { Strongly } \\
\text { Agree (\%) }\end{array}$ \\
\hline $\begin{array}{l}\text { The escape room encouraged me to think about } \\
\text { material in a new way }\end{array}$ & $4.3(.8)$ & 0 & 3.8 & 6.3 & 44.3 & 45.6 \\
\hline I would recommend this activity to other students & $4.4(.7)$ & 0 & 2.5 & 2.5 & 45.6 & 49.4 \\
\hline I learned from my peers during the diabetes escape room & $4.4(.6)$ & 0 & 1.3 & 2.5 & 50.6 & 45.6 \\
\hline $\begin{array}{l}\text { The escape room was an effective way to review } \\
\text { the topic of diabetes }\end{array}$ & $4.3(.7)$ & 0 & 1.3 & 7.6 & 53.2 & 38 \\
\hline $\begin{array}{l}\text { The escape room was an effective way to learn new } \\
\text { information related to diabetes }\end{array}$ & $4.2(.9)$ & 0 & 7.6 & 5.1 & 46.8 & 40.5 \\
\hline I learn better in a game format than in a didactic lecture & $4.0(.9)$ & 0 & 7.6 & 20.3 & 40.5 & 31.6 \\
\hline $\begin{array}{l}\text { The escape room was an effective way to assist my } \\
\text { learning of diabetes products }\end{array}$ & $4.3(.6)$ & 0 & 1.3 & 2.5 & 63.3 & 32.9 \\
\hline $\begin{array}{l}\text { I feel I was able to engage with my teammates to learn } \\
\text { new material }\end{array}$ & $4.4(.6)$ & 0 & 0 & 3.8 & 55.7 & 40.5 \\
\hline $\begin{array}{l}\text { It was difficult for me to focus on learning because I was } \\
\text { feeling stressed or overwhelmed }\end{array}$ & $3.7(.9)$ & 3.8 & 7.6 & 16.5 & 62 & 10.1 \\
\hline $\begin{array}{l}\text { The non-educational portions (eg, cyphers, puzzles, etc.) } \\
\text { distracted me from learning about diabetes }\end{array}$ & $3.4(1.0)$ & 5.1 & 11.4 & 29.1 & 43 & 11.4 \\
\hline $\begin{array}{l}\text { I prefer assembling information from a variety of sources } \\
\text { when learning new material }\end{array}$ & $3.8(.8)$ & 0 & 7.6 & 27.8 & 46.8 & 17.7 \\
\hline $\begin{array}{l}\text { In general, I enjoy playing games (video games, board } \\
\text { games, social media games, etc.) }\end{array}$ & $4.2(1.0)$ & 0 & 7.6 & 27.8 & 46.8 & 17.7 \\
\hline
\end{tabular}

$1=$ strongly disagree, $2=$ disagree, $3=$ neutral, $4=$ agree, $5=$ strongly agree

meaningful activities. ${ }^{5,6}$ As shown in the educational literature, ${ }^{8-11}$ gaming not only provides this type of learning context but also promotes both engagement and persistence on task, two critical conditions for deep learning. These positive outcomes of this teaching innovation provide a strong support for future iterations of refinement, implementation, and research of this game switching the focus of the research on the structure and effectiveness of students' actions and engagement during the game.

While the focus of this first deployment of the diabetes escape room was on the design and implementation, the researchers recognize some potential limitations of the study, especially related to the methods used to evaluate its impact. The use of a control group could strengthen the overall evaluation. However, since this was the first time this activity was used, the researchers chose not to pursue an experimental or quasi-experimental design due to potential ethical issues or to seek adoption of the same curriculum at a peer institution for comparison testing due to the complexity of coordinating such an attempt.

The escape room educational gaming concept could be adapted to other teaching topics or disease states at this institution or others. Costs associated with the activity were minimal as most materials were procured as free training devices from medication or diabetic supply manufacturers. Total start-up cost was less than $\$ 75$. Materials are re-used each year and future implementations require no additional costs. Time investment for creation of the puzzles and associated materials was approximately 20 hours and was partially delegated to an experiential education student on an elective academic rotation.

\section{CONCLUSION}

An innovative educational game, the diabetes escape room, was successfully piloted for P3 students at one school. Through this game, students improved their knowledge in diabetes management and reported a positive perceived value of this learning activity.

\section{ACKNOWLEDGMENTS}

The authors acknowledge Megan Hansen, PharmD, for her contributions to activity creation and implementation.

\section{REFERENCES}

1. Cranor CW, Bunting BA, Christensen DB. The Asheville Project: long-term clinical and economic outcomes of a community pharmacy diabetes care program. J Am Pharm Assn (Wash). 2003;43 (2):173-184.

2. Smith M. Pharmacists' role in improving diabetes medication management. J Diabetes Sci Technol. 2009;3(1):175-179.

3. Wongwiwatthananukit S, Zeszotarski P, Thai A, et al. A training program for pharmacy students on providing diabetes care. Am J Pharm Educ. 2013;77(7):Article 153.

4. Cain J, Conway JM, DiVall MV, et al. Report of the 2013-2014 Academic Affairs Committee. Am J Pharm Educ. 2014;78(10):Article S23. 


\section{American Journal of Pharmaceutical Education 2017; 81 (7) Article 6265.}

5. Brown JS, Collins A, Duguid P. Situated congnition and the culture of learning. Educl Researcher. 1989;18(1): $32-42$.

6. Schank RC, Berman TR, Macpherson KA. Learning by doing. In: Reigeluth C, ed. Instructional Design Theories and Models. A New Paradigm of Instructional Theory. New York, NY: Routledge; 2009:161-182.

7. French S, Marmor Shaw J. The unbelievably lucrative business of escape rooms. http://www.marketwatch.com/story/ the-weird-new-world-of-escape-room-businesses-2015-07-20.

Accessed July 16, 2016.
8. Cain J, Piascik P. Are serious games a good strategy for pharmacy education? Am J Pharm Educ. 2015;79(4):Article 47.

9. Simic G, Jemrevomic A, Kostic Z, Dordevics D. Assessment based on serious gaming. J Comput Assist Learn. 2015;31(6): 623-637.

10. Young MF, Slota S, Cutter AB, et al. Our princess is in another castle: a review of trends in serious gaming for education. Rev Educ Res. 2012;82(1):61-89.

11. Carvalho MB, Bellotti F, Berta RDG, Alessandro, et al. An activity theory-based model for serious games analysis and conceptual design. Comput Educ. 2015;87:166-181. 